\title{
10
}

Patrycja Mizera-Pęczek, Katarzyna Wojtaszczyk

Uniwersyet Łódzki

http://dx.doi.org/10.18778/8088-905-7.11

\section{Blog jako narzędzie wspierające kandydatów do pracy}

\section{Wstęp}

Rozwój mediów społecznościowych to nie tylko coraz większa liczba użytkowników portali oraz graczy w wirtualne gry na serio. Ekspansja mediów społecznościowych dotyczy także blogów czy mikroblogów (takich jak np. Twitter) cieszących się niesłabnącą popularnością. $W$ dobie łatwości komunikowania autorskich treści w internecie każdy może stać się twórcą i właścicielem bloga, a tematyka na nim podejmowana $\mathrm{w}$ zasadzie nie podlega ograniczeniom.

Analizy dotyczące możliwości współczesnych mediów społecznościowych pokazuja że korzystanie z tych narzędzi komunikacji może wspierać rozwój licznych umiejętności. Większość mediów społecznościowych pomaga wzbogacać kompetencje interpersonalne, szczególnie te dotyczące nawiązywania i podtrzymywania relacji online. $W$ przypadku korzystania z blogów mówi się także o doskonaleniu umiejętności krytycznej oceny oraz kształtowaniu umiejętności o charakterze technicznym. Prowadzenie własnego bloga może zatem przyczynić się do po- 
prawy sytuacji jednostki jako podmiotu rynku pracy, który, poszukując zatrudnienia, występuje $\mathrm{w}$ roli kandydata.

Tworzenie lub współtworzenie bloga jest także sposobem zaprezentowania się (swoich zainteresowań, doświadczeń, poglądów) szerokiemu gronu internautów. Ze względu na fakt, że informacji w sieci szukają nie tylko pasjonaci, lecz i pracodawcy, blogowanie stanowić może instrument „pokazania się" organizacji, która może się stać przyszłym miejscem zatrudnienia.

Zaprezentowane przesłanki zadecydowały o postawieniu tezy mówiącej o tym, że tworzenie lub współtworzenie bloga pomaga w znalezieniu zatrudnienia.

Artykuł ma charakter teoretyczno-empiryczny. We fragmentach teoretycznych zawarto treści traktujące o istocie blogowania i umiejętnościach kształtowanych poprzez prowadzenie bloga; kandydatach do pracy oraz kompetencjach, którymi, zgodnie z wynikami badań prowadzonych wśród pracodawców powinni legitymować się szukający zatrudnienia. Część badawcza pracy zawiera rezultaty badań własnych zrealizowanych zgodnie z podejściem „refleksyjnego praktyka”. W przeprowadzonej analizie odniesiono się głównie do doświadczeń jednej z autorek niniejszego artykułu, blogerki, współtwórczyni bloga „dajjoba”.

\section{Istota blogowania}

Blog to skrót terminu weblog, będącego połączeniem anglojęzycznych wyrazów web i log. Po raz pierwszy określenie to zostało użyte w 1997 r. Jego twórca, J. Barger, pracownik Northwestern University, posłużył się nim dla określenia osobistego wpisu na stronie internetowej. Dwa lata później P. Merholz zastosował pojęcie blog, rozbijając termin weblog na "we blog" (Okonek 2010: 4).

Potocznie pod pojęciem bloga rozumie się internetowy dziennik. Zgodnie z definicją, blog oznacza interaktywną stronę internetową poprzez którą jej twórca regularnie dostarcza zawartość czytelnikom (Deangdeelert 2012: 12). Blog jest: (1) oso- 
bisty - pisany przez osobę/osoby, a nie przez instytucję; (2) wirtualny - zazwyczaj nie jest drukowany, natomiast jest ciągle aktualizowany, a dla czytelników jest dostępny w internecie; (3) publikowany i upubliczniony - $\mathrm{w}$ znaczeniu technologicznym i w znaczeniu udostępniania bloga czytelnikom; (4) stanowi część wspólnoty - nie może istnieć samodzielnie, potrzebuje publiczności (Cywińska-Milonas 2002: 2). Założyciel bloga nazywany jest blogerem; dodawanie wpisów nosi nazwę blogowania (Schirmer 2011: 17). Blog może „istnieć” samoistnie lub być „połączony" ze stroną internetową albo kontem na portalu społecznościowym (Facebook, LinkedIn, Twitter) (Beshara 2012: 128). Najnowsze posty pojawiają się na głównej stronie bloga wraz z odnośnikami do archiwum zawierającego poprzednie wpisy (Wibbels 2007: 17). Innymi podstawowymi funkcjonalnościami blogów są możliwość komentowania wpisów przez czytelników oraz możliwość zamieszczania linków do innych stron internetowych, a szczególnie do blogów polecanych przez autora ( $\mathrm{tzw}$. blogroll) (Okonek 2010: 4).

Jak podkreślają autorzy raportu $B(V) \log$ Power (2015: 10), blogosfera stanowi bardzo ważny i duży obszar internetu. Choć dokładna liczba aktywnych blogów w naszym kraju nie jest znana, to wartość tę można oszacować na około 3 miliony (Garapich 2011). Skalę wpływu blogsfery na internautów w Polsce pokazują także następujące dane: rodzima blogosfera zrzesza niemal 11 milionów internautów; 56\% badanych użytkowników internetu deklaruje, że styka się z treściami zamieszczanymi na blogach lub vlogach (wideoblogach), a $45 \%$ z nich czyta lub ogląda je regularnie. Dzięki blogom zaspokajane są przede wszystkim potrzeby informacyjne internautów (52\% wskazań). Blogi także uczą (37\%), bawią (33\%), pokazują inny punkt widzenia (34\%), budują świadomość (30\%) i wspomagają decyzje zakupowe (29\%).

Najczęstszym powodem prowadzenia bloga jest chęć podzielenia się z innymi swoimi pasjami, zainteresowaniami, przemyśleniami. Jednak trzeba pamiętać, że blogowanie rozwija szereg umiejętności. Do najważniejszych z nich należy zaliczyć (Wankel 2011: 6-7; Stunża, Peszko 2013: 9): 
- umiejętności społeczne, głównie umiejętności pisemnego komunikowania się (łącznie z wzbogacaniem warsztatu pisarskiego) oraz nawiązywania i podtrzymywania znajomości online;

- umiejętności krytycznej oceny i weryfikacji informacji;

- umiejętności techniczne w zakresie projektowania i utrzymywania bloga.

Blogerzy budują wokół siebie społeczności (których liczebność uzależniona jest od atrakcyjności publikacji oraz promocji), na których opinie i decyzje mogą oddziaływać (Deangdeelert 2012: 13-14). Blogując, można pokazać innym swoje zaangażowanie i profesjonalizm (Hannon 2015: 180). Blogi, tak jak inne rodzaje mediów społecznościowych, stwarzają więc możliwość zaprezentowania kompetencji ich autorów szerokiemu gronu odbiorców (Stunża, Peszko 2013: 8). Powiedzieć zatem można, że prowadzenie bloga to pokazywanie swoich mocnych stron oraz szansa budowania marki osobistej, jest istotne z punktu widzenia zarządzania własną karierą czy poruszania się po rynku pracy.

$\mathrm{Z}$ mediów społecznościowych, a dokładnie $\mathrm{z}$ informacji zamieszczanych $\mathrm{w}$ sieci przez internautów, korzystają także pracodawcy poszukujący kandydatów do zatrudnienia. W różnego rodzaju mediów społecznościowych sprawdzają oni dane o aplikantach (porównują je z informacjami nadesłanymi w CV lub zawartymi $\mathrm{w}$ formularzach zgłoszeniowych), analizując wypowiedzi kandydatów na forach bądź w grupach dyskusyjnych, poznają ich poglądy, potrzeby i oczekiwania. Przyjąć więc należy, że prowadzenie bloga, będącego jednym z typów mediów społecznościowych, może się okazać dla poszukujących pracy narzędziem ważniejszym niż tradycyjne, drukowane wizy tówki (Covey, Colosimo 2014: 52).

Z jednej strony własny blog udowadnia potencjalnemu pracodawcy "autentyczność" kandydata (Waldman 2013: 138), który jest $\mathrm{w}$ stanie zaprezentować swoje wykształcenie, doświadczenie (także pozazawodowe) i kroki podjęte w celu znalezienia zatrudnienia (Doyle 2006: 100). Dzięki umieszczeniu na blogu własnego CV, portfolio lub artykułu oraz doborowi kolorystyki czy układu strony internetowej, pracodawca poznaje nie tylko „suche fakty” o potencjalnym kandydacie, lecz także 
pewne aspekty jego osobowości (Hannon 2015: 182). Z drugiej zaś - zamieszczenie na blogu szczegółowych danych o aktualnym miejscu pracy czy poufnych informacji o przyjaciołach lub znajomych może sugerować pracodawcy, że kandydat jest niedyskretny, a co za tym idzie, zostanie podjęta decyzja o niezakwalifikowaniu go do dalszych etapów selekcji (Doyle 2006: 101; Rogers 2011: 136).

\section{Kandydat do pracy}

Pojęcie „kandydata do pracy” jest rzadko definiowane w rodzimej literaturze. Potocznie kandydat to osoba zainteresowana podjęciem pracy, co oznacza złożenie $\mathrm{w}$ wybranej organizacji dokumentów aplikacyjnych i chęć udziału w procesie selekcji (Kostera, Kownacki 1998: 495).

Zgodnie z założeniem, że o sukcesie organizacji decydują zatrudnieni $\mathrm{w}$ nich ludzie, firmy koncentrują swoje starania na przyciągnięciu, zatrudnieniu i zatrzymaniu najlepszych pracowników, którzy będą zdolni do realizowania celów instytucji. Nie jest możliwe stworzenie uniwersalnego wzorca kandydata (który w przyszłości stanie się najlepszym pracownikiem). W ostatnich latach coraz częściej podkreśla się jednak, że aplikanta charakteryzować powinny: inicjatywa oddolna, zdolność twórczego myślenia, innowacyjność, umiejętność pracy w zespole, odpowiedzialność, całościowe spojrzenie na organizację, otwartość na zmiany, traktowanie problemów i trudności jako wyzwań, entuzjazm, gospodarność, autentyczna życzliwość i koleżeńskość (Dyląg 2004: 23).

Szczególną grupą kandydatów do pracy są absolwenci uczelni wyższych. W ramach badań „Uczelnia Przyjazna Pracodawcom" (Arendt 2010), prowadzonych przez Instytut Pracy i Spraw Socjalnych oraz eDialog, których celem było dokonanie oceny stopnia dostosowania absolwentów uczelni wyższych do wymogów rynku pracy, ustalono, czym kierują się pracodawcy w wyborze spośród kandydatów do pracy najlepszych pracow- 
ników. Według uzyskanych danych, do najważniejszych kryteriów wyboru kandydata należą: wiedza, umiejętności, doświadczenie zawodowe i kompetencje psychospołeczne. W przypadku absolwentów uczelni wyższych istotnym czynnikiem decydującym o znalezieniu zatrudnienia są także znajomości. Rezultat omawianych badań stanowi także zestaw umiejętności deficytowych, wskazanych przez pracodawców. Umiejętnością pożądaną przez pracodawców, lecz unikatowa, jest łączenie teorii z praktyką. Do umiejętności deficytowych, na które wskazało ponad 30\% spośród badanych respondentów zaliczają się również: organizacja pracy, obsługa klienta, umiejętność rozwiązywania problemów oraz znajomość języków obcych. Kolejno pracodawcy zwracali uwagę na niedostatek kreatywności, umiejętności współpracy w zespole, dostosowywania się do zmian, obsługi maszyn, urządzeń, umiejętności szybkiego uczenia się.

\section{Osobiste refleksje o prowadzeniu bloga}

Problematyka prowadzenia własnego bloga jest bliska autorkom niniejszego artykułu, które systematycznie monitorują media społecznościowe $\mathrm{w}$ poszukiwaniu nowych i wartościowych publikacji. Obie są zaangażowane $\mathrm{w}$ tworzenie treści przeznaczonych do publikacji na blogu swojego pracodawcy. Jedna z autorek jest współtwórczynią bloga poświęconego problematyce poszukiwania pracy i budowania kariery - dajjoba.wordpress.com.

W celu uzasadnienia postawionej tezy, metodykę pracy badawczej oparto na idei "refleksyjnego praktyka”. Podejście to zakłada, że nadawanie sensu dotychczasowym doświadczeniom praktyka (który jest jednocześnie badaczem) może prowadzić do ustalenia możliwych do zastosowania wytycznych, jak postępować w przyszłości (Drew, Bingham 2001: 221). W tym przypad$\mathrm{ku}$, refleksje dotyczące działań podejmowanych przez autorki $\mathrm{w}$ ramach blogowania doprowadziły do uzasadnienia, że tworzenie/współtworzenie bloga zwiększa szanse kandydatów na znalezienie zatrudnienia. 
Doświadczenia autorek opracowania oraz dyskusje o korzyściach, wynikających z publikowania swojej twórczości codziennej $\mathrm{w}$ internecie skłoniły do przemyśleń dotyczących: wzbogacania i porządkowania własnej wiedzy specjalistycznej dzięki tworzeniu bloga, nabywania umiejętności praktycznych, wynikających z użytkowania platformy do tworzenia blogów, możliwości kreowania swojej marki osobistej jako profesjonalisty dzięki publikowaniu wartościowych treści potwierdzających wysoki poziom wiedzy oraz stałe zainteresowanie uprawianą dyscypliną, a także możliwości autoekspresji.

Zasadniczą inspiracją do podzielenia się refleksjami wynikającymi z aktywnego uczestnictwa w blogosferze było współtworzenie bloga "dajjoba”. Głównym motywem stworzenia go (w roku 2014) było zbudowanie silnej marki osobistej przez jego autorki (Anna, Dagmara, Patrycja) dzięki zastosowaniu nowoczesnej formy CV/portfolio. Twórczynie miały także nadzieję, że nawiążą relacje z potencjalnymi pracodawcami i wykreują swoistą platformę networkingowa, umożliwiającą kontakt na linii poszukujący pracy - zatrudniający. W momencie zakładania bloga „,dajjoba” jego trzy autorki rozpoczynały poszukiwanie pracy zgodnej z oczekiwaniami i adekwatnej do zdobytego wykształcenia. Wszystkie studiowały wówczas stacjonarnie na II stopniu kierunku zarządzanie, $\mathrm{w}$ ramach specjalności zarządzanie zasobami ludzkimi w Uniwersytecie Łódzkim. Nie miały doświadczenia zawodowego, które umożliwiłoby znalezienie zatrudnienia na stanowisku specjalisty $\mathrm{w}$ obszarze zarządzania zasobami ludzkimi. Jednak każda z nich posiadała predyspozycje do pracy $\mathrm{w}$ obszarze kształtowania funkcji personalnej w organizacjach i była nastawiona na wzbogacanie wiedzy o studiowanej dyscyplinie oraz zdobywanie kolejnych doświadczeń zawodowych. Blog stał się zatem platformą służącą zaprezentowaniu swojego potencjału i - w odczuciu autorek - przestrzenią do udowodnienia, że są kandydatkami do pracy, które warto poznać.

Każda z autorek publikowała na blogu „dajjoba” treści, które były bliskie ich osobistym zainteresowaniom i mogły być ciekawe dla potencjalnych pracodawców (tab. 10.1). 
Tabela 10.1. Tematy podejmowane przez poszczególne autorki bloga „dajjoba”

\begin{tabular}{|c|c|c|}
\hline Anna & Dagmara & Patrycja \\
\hline $\begin{array}{l}\text { CV początkiem sukcesu } \\
\text { Niestandardowe rodza- } \\
\text { je CV } \\
\text { Jak napisać CV? } \\
\text { Are you motivated? } \\
\text { Co motywuje Cię do } \\
\text { pracy? } \\
\text { E-mail do pracodawcy } \\
\text { Udało się:) }\end{array}$ & $\begin{array}{l}\text { Ja, Spółka akcyjna } \\
\text { Twoja marka w me- } \\
\text { diach społecznościo- } \\
\text { wych } \\
\text { Networking? Twoja naj- } \\
\text { lepsza inwestycja! } \\
\text { Jestę Absolwentę! I co } \\
\text { dalej...? }\end{array}$ & $\begin{array}{l}\text { Hire me... please } \\
\text { Kreatywne (?) rozmo- } \\
\text { wy rekrutacyjne } \\
\text { Zawody przyszłości (?) } \\
\text { - post tylko trochę life- } \\
\text { stylowy } \\
\text { Myślenie - twórczość - } \\
\text { rozwój (1) } \\
\text { CV trendy - foto, opi- } \\
\text { nie, porady } \\
\text { Przełomy kariery }\end{array}$ \\
\hline
\end{tabular}

Źródło: opracowanie własne na podstawie dajjoba.wordpress.com

Dotychczasowe aktywności podejmowane na blogu były dla autorek sukcesem, który trudno zmierzyć. Obecnie każda z nich dostrzega pozytywy współprowadzenia strony, które wiążą się z możliwością rozpowszechniania wiedzy, dzielenia się doświadczeniami i spostrzeżeniami, pogłębiania kompetencji w interesujących dziedzinach, własnego rozwoju i zwrócenia uwagi potencjalnych pracodawców.

Już podczas rozmów kwalifikacyjnych, w których uczestniczyły twórczynie „dajjoba”, rekruterzy/selekcjonerzy wielokrotnie dopytywali o charakter bloga i motywy jego prowadzenia. Taka działalność była mile widziana przez pracodawców, niekiedy stawała się powodem zaproszenia autorek do wzięcia udziału $\mathrm{w}$ dalszych etapach selekcji (informacje o blogu były umieszczone w ich tradycyjnych $\mathrm{CV}$, odnośniki do bloga wzbogacały także profile zawodowe na portalach Goldenline, LinkedIn i Profeo).

Aktualnie każda z kreatorek ,dajjoba” jest związana zawodowo z obszarem zarządzania zasobami ludzkimi; wszystkie wykonują pracę zgodną z oczekiwaniami. Choć trudno udowodnić, że to właśnie prowadzenie bloga (a nie inne zmienne) przyczyniło się do zwiększenia szansy zatrudnienia, to z dużym prawdopodobieństwem pomogło jego współautorkom w wyznaczeniu kierunków rozwoju zawodowego. Już w momencie 
poszukiwania pierwszej pracy po ukończeniu studiów blogerki znały swoje mocne strony, posiadały dodatkową wiedzę specjalistyczną w dziedzinie zarządzania zasobami ludzkimi oraz umiejętności funkcjonowania w mediach społecznościowych, co wyróżniało je spośród innych kandydatów do pracy reprezentujących podobny poziom wykształcenia i doświadczenia zawodowego.

\section{Podsumowanie}

Jak starano się pokazać w niniejszym artykule, blog to narzędzie, które nie tylko doskonali warsztat pisarski autora oraz umiejętności techniczne potrzebne do prowadzenia tego typu platformy internetowej. Blogowanie to szansa zaprezentowania swoich mocnych stron oraz wzbogaceniaportfolio, będącego istotną składową marki osobistej pracownika (Wojtaszczyk 2015: 48).

Jednak, bez względu na korzyści, które niesie ze sobą blogowanie, warto zauważyć negatywne konsekwencje masowego tworzenia i komunikowania rożnego rodzaju treści w internecie. Przytoczone wartości liczbowe dotyczące rozwoju blogosfery potwierdzają że żyjemy obecnie w kulturze nadmiaru. „Jesteśmy zasypywani obrazami, dźwiękami, performansami, słowami, produktami i usługami" (Szlendak 2013: 7), ponieważ każdy znajduje w sieci przestrzeń do zaprezentowania swojej twórczości, bez względu na to, czy jest amatorem, czy profesjonalistą w uprawianej dyscyplinie. T. Szlendak zauważa, że internetowy zalew publikacji to treści zmultiplikowane, banalne, nie zawierające pierwiastka nowości. „Wszystkiego pełno, ale to wszystko jest tym samym" (2013: 11). Wydaje się zatem, że blog spełni swoją rolę narzędzia wspierającego kandydata w poszukiwaniu pracy jedynie wtedy, gdy będzie autentyczny, prowadzony rzetelnie, interesujący dla czytelnika, wzbogacony wartościowymi przemyśleniami autora, a podejmowane na nim problemy nie będą nieudolną próbą udowodnienia swojego potencjału kreatywności. 


\section{Literatura}

Arendt Ł. (2010), Raport z badań w projekcie Uczelnia Przyjazna Pracodawcom, IPiSS, eDialog, Warszawa.

Beshara T. (2012), The Job Search Solutions, Amacom, New York.

$B(V)$ Log Power. Wpływ blogów i wideoblogów na internautów (2015), Polskie Stowarzyszenie Blogerów i Vlogerów, http://www.psbv.pl/BlogPower_raport. pdf [dostęp: 20.04.2016].

Covey S. R., Colosimo J. (2014), Great Work, Great Career. How to Create Your Ultimate Job and Make an Extraordinary Contribution, Franklin Covey Co., Miami.

Cywińska-Milonas M. (2002), Blogi. Ujęcie psychologiczne, [w:] Liternet. Literatura i internet, red. P. Marecki, Rabid, Kraków.

Deangdeelert Cho J. (2012), Blog Inc. Blogging for Passion, Profit, and to Create Community, Chronicle Books, San Francisco.

Doyle A. (2006), The About.com Guide to Job Searching: Tools and Tactics to Help You Get the Job You Want, Adams Media, Avon.

Drew S., Bingham R. (2001), The Student Skills Guide, "Aldershot Gower Journal: Reflective Practice".

Dyląg A. (2004), Praca - kariera - wypalenie zawodowe, [w:] Człowiek i psychologia, red. J. Rybakiewicz, Wydawnictwo Park, Bielsko-Biała.

Garapich A. (2011), PBI o blogosferze w Polsce, http://www.slideshare.net/domino00/blogosfera-w-liczbach [dostęp: 24.05.2016].

Hannon K. (2015), Getting the Job You Want After 50, John Wiley \& Sons, Hoboken.

Kostera M., Kownacki S. (1998), Zarzadzanie potencjatem społecznym organizacji, [w:] Zarzadzanie. Teoria i praktyka, red. A. K. Koźmiński, W. Piotrowski, Wydawnictwo Naukowe PWN, Warszawa.

Okonek P. (2010), Przyszłość blogosfery, Polska Agencja Rozwoju Przedsiębiorczości, Warszawa.

Rogers J. (2011), Great Answers to Tough CV Problems, Kogan Page, London-Philadelphia.

Schirmer J. (2011), Fostering meaning and community In Whiting via social media, [w:] Ch. Wankel (ed.), Teaching Arts and Science with the New Social Media, Emerald Group Publishing, Bingley.

Stunża G., Peszko P. (2013), (Nie)bój się bloga! Jak wykorzystywać blog w edukacji, Instytut Kultury Miejskiej, Gdańsk.

Szlendak T. (2013), Kultura nadmiaru w czasach niedomiaru, „Kultura Współczesna. Teorie. Interpretacje. Praktyka", nr 1.

Waldman J. (2013), Job Searching with Social Media, John Wiley \& Sons, Hoboken.

Wankel Ch. (2011), New dimensions of communicating with students: introduction to teaching arts and science with the new social media, [w:] Ch. Wankel (ed.), Teaching Arts and Science with the New Social Media, Emerald Group Publishing, Bingley. 
Wibbels A. (2007), Prowadź blog! Przewodnik dla małych firm, Wydawnictwo Helion, Gliwice.

Wojtaszczyk K. (2015), Samokształcenie w mediach społecznościowych narzędziem rozwoju zasobów ludzkich organizacji, [w:] Wybrane problemy w kształtowaniu zachowań organizacyjnych, red. M. Makowiec, Uniwersytet Ekonomiczny w Krakowie, Kraków. 